\title{
Pengaruh Jumlah Penduduk, Indeks Pembangunan Manusia Dan Angkatan Kerja Terhadap Kemiskinan Di Provinsi Jambi
}

\author{
Sudirman $^{1 *}$, Sakinah $^{2}$ \\ ${ }^{1,2}$ Fakultas Ekonomi Universitas Batanghari \\ *Correspondence email: sudirmanidris8@gmail.com; sakinah.as64@gmail.com
}

\begin{abstract}
Abtract. This research is quantitative research that wants to see the influence of Population, Human Development Index and Labor Force on Poverty in Jambi Province. The data used is time series data in 2000 - 2019 while the analysis tool used is multiple linear regression using Eviews 8 as an analysis tool. In this study concluded that the number of productive populations, manusi development index and workforce is able to minimize poverty in Jambi Province.
\end{abstract}

Keyword: the population; development; Poverty

\section{Pendahuluan}

BPS (2002), pengertian kemiskinan umumnya selalu dikaitkan hanya dengan sektor ekonomi semata. Padahal kemiskinan bisa dilihat dari sisi sosial maupun budaya masyarakat. Pada prinsipnya kemiskinan menggambarkan kondisi ketiadaan kepemilikan dan rendahnya pendapatan, atau secara lebih rinci menggambarkan suatu kondisi tidak dapat terpenuhinya kebutuhan dasar manusia, yaitu pangan, papan, dan sandang. Beberapa definisi menggambarkan kondisi ketiadaan tersebut. Salah satunya adalah definsi kemiskinan yang digunakan BPS, yang menjelaskan kemiskinan sebagai ketidakmampuan individu dalam memenuhi kebutuhan dasar minimal untuk hidup layak. Saharuddin dkk (2016), kemiskinan dapat diatasi dengan menekan angka kelahiran atau pertumbuhan jumlah penduduk yang tinggi, jumlah penduduk yang tinggi sangat berpengaruh terhadap pertumbuhan jumlah angka kemiskinan. Sugi dkk (2019), kemiskinan merupakan sesuatu yang sering menjadi ukuran keberhasilan kepemimpinan seorang kepala daerah. Selain itu juga sebagai tujuan pertama Sustainable Development Goals (SDG's) untuk dientaskan. Kebijakan yang tepat sangat penting dibuat demi tercapainya tujuan pembangunan berkelanjutan. Pemodelan Geographically Weighted Regression (GWR) penting digunakan untuk menyusun model di setiap kabupaten/kota sebagai dasar pembuat kebijakan. Hamzah dkk (2019), investasi tidak berpengaruh terhadap angka kemiskinan, sedangkan inflasi sangat signifikan terhadap jumlah penduduk miskin. Jumlah penduduk miskin di setiap daerah dijelaskan oleh berbagai macam variable baik variable ekonomi maupun variable non ekonomi.

Adapun gambaran perkembangan kemiskinan pemerintah Provinsi Jambi tahun 2010-2019 sebagaimana terlihat pada Tabel 1 dibawah ini. Angka kemiskinan jika diteliti secara keseluruhan di Provinsi Jambi sangat berfluktuasi.

Tabel 1

Angka Kemiskinan Provinsi Jambi Tahun 2010-2019

\begin{tabular}{ccc}
\hline Tahun & Angka Kemiskinan (Jiwa) & Perkembangan (Persen) \\
\hline 2010 & 260.400 & $-3,30$ \\
2011 & 251.800 & 6,63 \\
2012 & 268.500 & 3,43 \\
2013 & 277.700 & 1,46 \\
2014 & 281.750 & 6,73 \\
2015 & 300.710 & $-3,62$ \\
2016 & 289.810 & $-1,12$ \\
2017 & 286.550 & $-1,32$ \\
2018 & 282.766 & $-2,99$ \\
2019 & 274.320 & 0,66 \\
Rata-Rata & 277.431 & 201 \\
\hline
\end{tabular}

Sumber: (http://www.bi.go.id), dan BPS Provinsi Jambi 2020

Laju penurunan jumlah penduduk miskin tertinggi terjadi pada tahun 2011, yaitu sebesar 251.800 jiwa atau turun sebesar 3,30 persen. Penurunan jumlah penduduk miskin di Provinsi Jambi ini tidak terlepas dari berbagai kebijakan pemerintah pusat dan pemerintah Provinsi Jambi sendiri yang mampu memberikan stimulus pengurangan jumlah penduduk miskin. Selama periode 2010-2019 angka kemiskinan penduduk Provinsi Jambi mengalami peningkatan sebesar 0,66 persen pertahun. Peningkatan jumlah penduduk miskin memberikan gambaran bahwa laju 
pertumbuhan ekonomi yang cenderung positif diikuti pula dengan kecenderungan penurunan jumlah penduduk miskin.

Memetakan angka kemiskinan tidak cukup hanya menghitung jumlah orang miskin. Akan tetapi pemerintah juga perlu mengetahui tingkat kedalaman dan keparahan kemiskinan di Provinsi Jambi. Kemiskinan memiliki tingkat kedalaman dan keparahan kemiskinan yang beragam, sehingga alokasi dana untuk pengentasan kemiskinan perlu menimbang faktor tersebut. Berikut ini dapat dilihat perkembangan persentase penduduk miskin (P0), indeks kedalaman kemiskinan (P1) dan indeks keparahan kemiskinan (P2) Provinsi Jambi selama tahun 2010-2019 yang dapat dilihat dari Tabel 1 dibawah ini :

Tabel 2

Perkembangan Persentase Penduduk Miskin (P0), Indeks Kedalaman Kemiskinan (P1) Dan Indeks Keparahan Kemiskinan (P2) Provinsi Jambi Selama Tahun 2010-2019

\begin{tabular}{crrr}
\hline Tahun & Persentase Penduduk Miskin (P0) & Indeks Kedalaman Kemiskinan (P1) & Indeks Keparahan Kemiskinan (P2) \\
\hline 2010 & 8,40 & 1,21 & 0,30 \\
2011 & 7,90 & 1,02 & 0,23 \\
2012 & 8,28 & 1,37 & 0,26 \\
2013 & 8,41 & 1,12 & 0,26 \\
2014 & 8,39 & 1,12 & 0,23 \\
2015 & 8,86 & 1,42 & 0,35 \\
2016 & 8,41 & 1,47 & 0,37 \\
2017 & 8,19 & 1,28 & 0,29 \\
2018 & 7,92 & 1,30 & 0,32 \\
2019 & 7,60 & 1,23 & 0,30 \\
Rerata & 8,24 & 1,25 & 0,29 \\
\hline
\end{tabular}

Sumber: (http://www.bi.go.id), dan BPS Provinsi Jambi 2020

Berdasarkan Tabel 2 diatas terlihat persentase pendudukan miskin (P0) selama periode 2010 hingga 2019 ratarata 8,24 persen. Sedangkan untuk indeks kedalaman kemiskinan (P1) dan indeks keparahan kemiskinan (P2) di periode tahun yang sama masing-masing rata-rata 1,25 unttuk indeks kedalaman kemiskinan (P1) dan 0,29 untuk indeks keparahan kemiskinan (P2)

\section{Landasan Teori}

\section{Teori Kemiskinan}

Lanjouw dalam Mirza (2011) menyatakan pembangunan manusia di Indonesia adalah identik dengan pengurangan kemiskinan. Investasi di bidang pendidikan dan kesehatan akan lebih berarti bagi penduduk miskin dibandingkan penduduk tidak miskin, karena aset utama penduduk miskin adalah tenaga kasar mereka. Tersedianya fasilitas pendidikan dan kesehatan murah akan sangat membantu untuk meningkatkan produktivitas, dan pada gilirannya meningkatkan pendapatan. Dengan demikian dapat dikatakan bahwa pembangunan manusia belum secara optimal dilakukan karena hanya terfokus pada pengurangan kemiskinan. Kuncoro (2006) mendefenisikan kemiskinan sebagai ketidakmampuan untuk memenuhi standar hidup minimum. Dimensi-dimensi kemiskinan tersebut termanifestasikan dalam bentuk kekurangan gizi, air, perumahan yang tidak sehat, perawatan kesehatan yang kurang baik, dan tingkat pendidikan yang rendah. Kedua, aspek-aspek kemiskinan saling berkaitan baik secara langsung maupun tidak langsung. Hal ini. Hal ini berarti bahwa kemajuan dan atau kemunduran pada salah satu aspek dapat mempengaruhi kemajuan atau kemunduran pada aspek lainnya. Ketiga, bahwa yang miskin adalah manusianya, baik secara individual maupun kolektif. Dimana kita sering mendengar perkataan kemiskinan perkotaan (urban poverty) dan kemiskinan pedesaan (rural poverty).

Todaro (2003) mengungkapkan bahwa generalisasi yang paling tepat tentang kemiskinan adalah mereka yang ditempatkan di daerah pedesaan secara tidak seimbang, dan terutama sekali mereka yang bekerja di bidang pertanian atau kegiatan-kegiatan usaha bersama mengungkapkan bahwa dilihat dari faktor penyebabnya dapat dikategorikan dalam beberapa jenis, yaitu :

1. Kemiskinan alamiah; yaitu kemiskinan timbul disuatu daerah karena sumberdaya alamnya kurang mendukung terhadap penghidupan penduduk, misalnya kering, tandus, rawan bencana alam.

2. Kemiskinan struktural, yaitu kemiskinan yang timbul disuatu wilayah karena daerahnya tidak mempunyai sarana dan prasarana untuk menunjang penghidupan masyarakat, sehingga penduduk tidak mempunyai akses untuk mendapatkan peluang ekonomi yang ada.

3. Kemiskinan kultural, yaitu kemiskinan yang timbul karena faktor sifat dan budaya manusia itu sendiri yang kurang mendukung untuk perbaikan kehidupannya seperti malas, menerima apa adanya, kurang tanggap terhadap kemajuan pembangunan. 
4. Kemiskinan temporer, yaitu keadaan keluarga penduduk menjadi miskin sebagai akibat bencana alam, seperti kebakaran, kebanjiran, gempa bumi.

Smith dalam Hamzah, dkk (2019)akumulasi modal menerapkan syarat utama dalam pembangunan ekonomi yaitu bagaimana kemampuan manusia untuk lebih banyak menabung dan menanamkan modalnya. Tujuan Pembangunan ekonomi adalah membangun peralatan modal dengan skala yang cukup untuk meningkatkan produktivitas.. Todaro dalam Arsyad, (2015).Tingkat pendapatan minimum merupakan pembatas antara keadaaan miskin dengan tidak miskin atau sering disebut sebagai garis batas kemiskinan. Konsep ini sering disebut dengan kemiskinan absolut. Konsep ini dimaksudkan untuk menentukan tingkat pendapatan minimum yang cukup untuk memenuhi kebutuhan fisik terhadap makanan, pakaian, dan perumahan untuk menjamin kelangsungan hidup.

Arsyad (2015). Kesulitan utama dalam konsep kemiskinan absolut adalah menentukan komposisi dan tingkat kebutuhan minimum karena kedua hal tersebut tidak hanya dipengaruhi oleh adat kebiasaan saja, tetapi juga oleh iklim, tingkat kemajuan suatu negara, dan berbagai faktor ekonomi lainnya. Walaupun demikian, untuk dapat hidup laik seseoarang membutuhkan barang-barang dan jasa untuk memenuhi kebutuhan fisik dan sosialnya.

BPS (2016), Garis kemiskinan ditetapkan dengan terlebih dahulu menghitung batas kecukupan makanan (pangan) dan batas kecukupan non makanan. Batas kecukupan pangan dihitung dari besarnya rupiah yang dikeluarkan untuk makanan yang memenuhi kebutuhan minimum energy sebesar 2.100 kalori perhari. Patokan ini mengacu pada hasil widyakarya pangan dan gizi tahun 1978. Dari data susenas yang ditabelkan ke dalam 11 pengeluaran, kemudian dihitung rata-rata harga kalori untuk masing-masing kelas pengeluaran tersebut. Oleh karena kebutuhan manusia tidak hanya mencakup kebutuhan makanan saja, namun juga harus terpenuhi kebutuhan non makanan seperti perumahan, sandang, kesehatan, pendidikan, transportasi, dan lainnya, maka nilai pengeluaran untuk mencukupi 2.100 kalori harus ditambah dengan pengeluaran minimum makanan ditambah kebutuhan minimum non makanan. Inilah yang disebut garis kemiskinan.

\section{Jumlah Penduduk}

Usman dkk (2018). Besarnya Pengaruh Jumlah Penduduk, Pengangguran dan Pertumbuhan Ekonomi terhadap Kemiskinan di Provinsi Kepulauan Riau. BPS, (2016). Penduduk suatu negara merupakan objek dan subjek pembangunan. Sebagai obyek artinya penduduk merupakan faktor yang harus dibangun atau ditingkatkan kualitas hidupnya. Sebagai subjek penduduk merupakan faktor pelaku proses pembangunan. Di lihat dari sisi yang lain, penduduk merupakan beban sekaligus potensi bagi suatu negara. Apabila suatu negara pertumbuhan penduduknya sangat tinggi, ini merupakan masalah. Hal ini dikarenakan kapasitas wilayah suatu Negara terbatas.

Subrini dalam sudirman (2014) Tenaga kerja adalah penduduk dalam usia (berusi 15-64 tahun) atau jumlah seluruh penduduk dalam suatu negara yang dapat memproduksi barang dan jasa jika ada permintaan terhadap tenaga mereka dan jika mereka mau berpartisipasi dalam aktivitas tersebut.

\section{Teori Indeks Pembangunan Manusia}

Sari, dkk (2020). Rendahnya produktivitas kaum miskin dapat disebabkan oleh rendahnya akses mereka untuk memperoleh pendidikan. Todaro (2003) juga mengatakan bahwa pembangunan manusia merupakan tujuan pembangunan itu sendiri. Yang mana pembangunan manusia memainkan peranan kunci dalam membentuk kemampuan sebuah negara dalam menyerap teknologi modern dan untuk mengembangkan kapasitasnya agar tercipta pertumbuhan serta pembangunan yang berkelanjutan. indeks pembangunan manusia memuat tiga dimensi penting dalam pembangunan yaitu terkait dengan aspek pemenuhan kebutuhan akan hidup panjang umur (Longevity) dan hidup sehat (healthy life), untuk mendapatkan pengetahuan (the knowledge) dan mempunyai akses kepada sumberdaya yang bisa memenuhi standar hidup. Artinya, tiga dimensi penting dalam pembangunan manusia tersebut sangat berpengaruh terhadap kemiskinan. BPS, (2016). Angka Harapan Hidup (AHH), dijadikan indikator dalam mengukur tingkat kesehatan suatu individu di suatu daerah. Angka Harapan Hidup saat lahir adalah rata-rata tahun hidup yang akan dijalani oleh bayi yang baru lahir pada suatu tahun tertentu.

\section{Teori Angkatan Kerja}

Arsyad, (2015). masalah sempitnya kesempatan kerja merupakan salah satu akar permasalahan kemiskinan. Malthis dalam Sudirman (2017) Produktivitas mengikutsertakan pendaya gunaan secara terpadu sumber daya manusia dan keterampilan, barang modal, teknologi manajemen, informasi, energi dan sumber-sumber lain kepada pengembangan dan peningkatan standar untuk seluruh masyarakat melalui konsep produktivitas persemester. Sumarsono (2007) Menurut pendapat dari Sumarsono, angkatan kerja ialah bagian penduduk yang sanggup dan bersiap untuk menjalankan suatu pekerjaan.. Arsyad (2015). Penyerapan angkatan kerja yang tinggi belum tentu berdampak pada pengurangan kemiskinan. Selama empat dekade terakhir beberapa negara sedang berkembang 
mengalami pertumbuhan ekonomi yang pesat namu tidak berhasil mengurangi angka kemiskinan yang begitu memprihatinkan. Sukirno (2004). terdapat pengaruh langsung antara pertambahan penduduk terhadap tingkat kesejahteraan masyarakat. Nelson dan Leibenstein menunjukan bahwa pertumbuhan penduduk yang pesat di negara berkembang menyebabkan tingkat kesejahteraan masyarakat tidak mengalami perbaikan yang berarti dan dalam jangka panjang akan mengalami penurunan kesejahteraan serta meningkatkan jumlah penduduk miskin.

\section{Metode}

Model persamaan regresi dalam penelitian ini dengan spesifikasi model dasar sebagai berikut:

Poverty $=f\{J P, I P M, A K\}$, berdasarkan model dasar dapat di formulasikan menjadi persamaan regresi linear berganda dengan data time series sebagai berikut :

$\operatorname{LogPoverty}_{\mathrm{t}}=\beta_{0 \mathrm{t}}+\beta_{1} \operatorname{LogJP} \mathrm{P}_{\mathrm{t}}+\beta_{2} \mathrm{IPM}_{\mathrm{t}}+\beta_{3} \log _{\mathrm{AK}}+\mu_{\mathrm{t}}$

Keterangan: Poverty = Jumlah Penduduk Miskin (Jiwa); JP = Jumlah Penduduk Produktif usia 15-65 tahun Provinsi Jambi (Jiwa); IPM = Indeks Pembangunan Manusia Provinsi Jambi (Tahun); AK = Angkatan Kerja khusus orang yang bekerja Provinsi Jambi (Jiwa); Log = Logaritma; $\beta_{0}=$ Konstanta; $\beta_{1}, \beta_{2}, \beta_{3}=$ koefisien regresi untuk masing-masing variabel bebas; $\mu=$ standar error; $t=$ waktu

Menurut Boediono (2000) Untuk hubungan variabel Jumlah Penduduk (penduduk yang usia produktif) (JP), Indeks Pembangunan Manusia (IPM) dan angkatan kerja (penduduk bekerja) (AK) dengan kemiskinan (KEMIS) di Provinsi Jambi secara umum, menggunakan model analisis korelasi pearson dengan sofware Eviews versi 0.8 yang dapat digambarkan dalam fungsi sebagai berikut:

$\mathrm{r}=\frac{n \sum x y-\Sigma x \Sigma y}{\sqrt{n \sum x^{2}-(\Sigma x)^{2}} \sqrt{\Sigma y^{2}-(\Sigma y)^{2}}}$

dimana: $\mathrm{r}=$ koefisien korelasi; $\mathrm{n}=$ jumlah periode; $\mathrm{y}=$ realisasi kemiskinan; $\mathrm{x}=$ realisasi variabel $\mathrm{yang}$ mempengaruhi.

terdiri dari:

Ghozali (2009) Pengujian regresi linier berganda dengan menggunakan Ordinat Least Square (OLS) yang

a. Uji Signifikansi Parameter Individual (Uji Statistik t), pada tingkat signifikansi $\alpha=5 \%$ dengan pengujian yang digunakan adalah sebagai berikut : $\mathrm{H}_{0}$ ditolak $\mathrm{H}_{1}$ diterima apabila $\mathrm{t}$ statistik $>\mathrm{t}$ nilai probabilitas ( $p$ value), yang berarti variabel independennya $(X)$ berpengaruh secara signifikan terhadap variabel dependen.

b. Uji Signifikansi Simultan (Uji Statistik F)

Hipotesis yang digunakan :

$\mathrm{H}_{0}: \beta_{1}=\beta_{2}=0$

$\mathrm{H}_{1}$ : minimal ada satu koefisien regresi tidak sama dengan nol

Pada tingkat signifikansi $\alpha=5 \%$ dengan kriteria pengujian yang digunakan sebagai berikut :

- $\mathrm{H}_{0}$ diterima dan $\mathrm{H}_{1}$ ditolak apabila $\mathrm{F}$ statistik < F tabel, yang artinya variabel penjelas secara serempak atau bersama-sama tidak mempengaruhi variabel yang dijelaskan secara signifikan.

- $\mathrm{H}_{0}$ ditolak dan $\mathrm{H}_{1}$ diterima apabila $\mathrm{F}$ hitung > $\mathrm{F}$ tabel, yang artinya variabel penjelas secara serentak dan bersama-sama mempengaruhi variabel yang dijelaskan secara signifikan.

c. Koefisien Determinasi, koefisien determinasi $\mathrm{R}^{2}$ pada intinya mengukur seberapa jauh kemampuan model dalam menerangkan variasi variabel independent. Nilai koefisien determinasi di antara 0 dan $1\left(0<\mathrm{R}^{2}<1\right)$, nilai $\left(\mathrm{R}^{2}\right)$ yang kecil berarti kemampuan variabel-variabel independen dalam menjelaskan variasi variabel independent sangat terbatas. Nilai yang mendekati 1 berarti variabel independent memberikan hampir semua informasi yang dibutuhkan untuk memperoleh prediksi variasi model dependent.

\section{Hasil}

Tabel 3

Hasil Regresi Linear Berganda dengan Eviews 8.0

\begin{tabular}{|l|r|r|r|r|}
\hline \multicolumn{1}{|c|}{ Variable } & Coefficient & Std. Error & \multicolumn{1}{c|}{ t-Statistic } & Prob. \\
\hline LOG1 & -1.370422 & 0.642753 & -2.132114 & 0.0488 \\
\hline LOG2 & -1.102825 & 0.537803 & -2.050611 & 0.0571 \\
\hline LOG3 & 0.988259 & 0.529241 & 1.867315 & 0.0803 \\
\hline C & 10.29645 & 1.474900 & 0.981120 & \\
\hline R-squared & 0.404717 & Mean dependent var & 5.454843 \\
\hline Adjusted R-squared & 0.293102 & S.D. dependent var & 0.037077 \\
\hline S.E. of regression & 0.031173 & Akaike info criterion & -3.921658 \\
\hline Sum squared resid & 0.015548 & Schwarz criterion & -3.722512 \\
\hline
\end{tabular}


Sudirman dan Sakinah, Pengaruh Jumlah Penduduk, Indeks Pembangunan Manusia Dan Angkatan Kerja Terhadap Kemiskinan Di Provinsi Jambi

\begin{tabular}{|l|c|l|c|}
\hline Log likelihood & 43.21658 & Hannan-Quinn criter. & -3.882783 \\
\hline F-statistic & 3.625992 & Durbin-Watson stat & 0.936017 \\
\hline Prob(F-statistic) & 0.036056 & & \\
\hline
\end{tabular}

Sumber: data olahan

LogPoverty $_{t}=10.297-1,370 \operatorname{logpdd} d_{t}-1,102 \operatorname{LogIPM}_{t}+0,988 \log _{\mathrm{A}} \mathrm{K}_{\mathrm{t}}+\mu_{\mathrm{t}}$

Persamaan dapat diintepretasikan dalam pembahasan dan hasil sebagai berikut :

Nilai angka koefisien $\beta_{0}$ sebesar 10.297 artinya, apabila pada periode 2000-2019 tidak terjadi perubahan jumlah penduduk (JP), indeks pembangunan manusia (IPM) dan angkatan kerja (AK) atau dengan asumsi konstan, maka kemiskinan (POVERTY) di Provinsi Jambi adalah mengalami peningkatan sebesar 10.297 jiwa pertahun. Ini mengindikasikan bahwa uraian hasil regresi dapat terlihat bahwa meski variabel bebas stagnan namun tetap meningkatkan kemiskinan Provinsi Jambi. Berdasarkan hasil penelitian diatas terlihat pemerintah daerah berupaya meminimalisasi kemiskinan melalui peningkatkan Angkatan Kerja, tetapi belum dapat mengatasi kemiskinan yang terjadi di Provinsi Jambi.

Untuk koefisien regresi variabel Jumlah Penduduk (JP) $\left(\beta_{1}\right)$ diperoleh nilai sebesar -1,370 artinya apabila terjadi kenaikan atau peningkatan Jumlah penduduk (JP) sebesar 1 persen, maka akan menurunkan kemiskinan di Provinsi Jambi sebesar -1,370 persen dengan asumsi bahwa variabel lain tetap (Cateris paribus) atau tidak terjadi perubahan atau konstan. Dalam hal ini dijelaskan upaya penanggulangan kemiskinan pemerintah daerah daerah belum optimal, akibat dari pesatnya pertumbuhan ekonomi yang tidak diikuti sistem pengendalian lonjakan urbanisasi manusia terhadap mobilitas faktor produksi. Sehingga potensi yang dimiliki daerah menjadi daya tarik bagi daerah sekitar. Hal ini menjadi bomerang negatif terhadap penggentasan kemiskinan, sehingga pertumbuhan ekonomi yang tinggi berdampak kecil pada penurunan angka kemiskinan di Provinsi Jambi.

Begitu juga koefisien regresi variabel Indek Pembangunan Manusia (IPM) $\left(\beta_{2}\right)$ diperoleh nilai sebesar $-1,102$ artinya apabila terjadi kenaikan atau peningkatan Indek Pembnagunan Manusia (IPM) di Provinsi Jambi sebesar 1 persen, maka akan menurunkan kemiskinan sebesar -1,102 persen dengan asumsi bahwa variabel lain tetap (Cateris paribus) atau tidak terjadi perubahan atau konstan. Sedangkan koefisien regresi variabel Angkatan Kerja (AK) $\left(\beta_{3}\right)$ diperoleh nilai sebesar 0,988 artinya apabila terjadi kenaikan atau peningkatan jumlah Angkatan Kerja (AK) sebesar 1 persen, maka akan meningkatkan kemiskinan Provinsi Jambi sebanyak 0,988 persen dengan asumsi bahwa variabel lain tetap (Cateris paribus) atau tidak terjadi perubahan atau konstan.

\section{Uji Parsial (Uji t)}

Berdasarkan uji statistik parsial dengan tingkat keyakinan $\alpha=5 \%$, diperoleh nilai t-statistik untuk variabel Jumlah Penduduk $(\mathrm{JP})\left(\beta_{1}\right)$ yang nilainya lebih besar dari t-prob $(0.0488<0,05)$, artinya. Perobahan jumlah penduduk produktif (JP) selama periode 2000-2019 berpengaruh signifikan terhadap penurunan angka kemiskinan (Poverty) di Provinsi Jambi, dengan tingkat keyakinan dibawah $\alpha=5 \%$. Sedangkan untuk variabel Indek Pembangunan Manusia (IPM) $\left(\beta_{2}\right)$ diperoleh nilai yang lebih besar dari t-prob $(0.0571 \geq 0,05)$, artinya bahwa Indek Pembangunan Manusia (IPM) berpengaruh signifikan terhadap penurunan angka kemiskinan (Poverty) di Provinsi Jambi, dengan tingkat keyakinan diatas $\alpha=5 \%$

Nilai t-statistik untuk variabel Angkatan Kerja $(\mathrm{AK})\left(\beta_{3}\right)$ signifikan terhadap peningkatan kemiskinan Provinsi Jambi. Berdasarkan hasil diperoleh nilai yang lebih besar dari t-prob $(0.0803>0,05)$, artinya $\mathrm{H}_{0}$ ditolak $\mathrm{H}_{1}$ diterima. Artinya bahwa Angkatan Kerja (AK) $\left(\mathrm{X}_{3 \mathrm{t}}\right)$ berpengaruh signifikan terhadap peningkatan kemiskinan (Poverty ) di Provinsi Jambi pada tingkat keyakinan $\alpha$ dibawah $5 \%$

\section{Uji Simultan (Uji-F)}

Tabel 4

Uji F-Statistik

\begin{tabular}{|l|l|l|r|}
\hline R-squared & 0.404717 & Mean dependent var & 5.454843 \\
\hline Adjusted R-squared & 0.293102 & S.D. dependent var & 0.037077 \\
\hline S.E. of regression & 0.031173 & Akaike info criterion & -3.921658 \\
\hline Sum squared resid & 0.015548 & Schwarz criterion & -3.722512 \\
\hline Log likelihood & 43.21658 & Hannan-Quinn criter. & -3.882783 \\
\hline F-statistic & 3.625992 & Durbin-Watson stat & 0.936017 \\
\hline Prob(F-statistic) & 0.036056 & & \\
\hline
\end{tabular}


Berdasarkan persamaan Tabel 4, diperoleh nilai F-statistiknya lebih besar dari nilai F-prob $(0.036056<0,05)$ pada tingkat keyakinan $\alpha=5 \%$. Artinya,. Ini menunjukan bahwa secara bersama-sama variabel Jumlah Penduduk (JP), Indeks pembangunan manusia (IPM) dan angkatan kerja (AK) berpengaruh signifikan terhadap naik turunnya kemiskinan (Poverty) di Provinsi Jambi selama periode 2000 sampai dengan 2019.

\section{Tingkat Signifikansi R-Squared $\left(R^{2}\right)$}

Hasil perhitungan R- squared yang ditunjukkan pada persamaan diatas diperoleh nilai sebesar 0.4047. Hal ini menunjukan bahwa sekitar 40,47 persen naik turunnya kemiskinan (Poverty) di Provinsi Jambi mampu di jelaskan oleh jumlah penduduk (JP), indeks pembangunan manusia (IPM) dan angkatan kerja (AK). Sedangkan sisanya 59,53 persen, dijelaskan oleh variabel lain.

\section{Simpulan}

Jumlah penduduk usia produksif adalah salah satu indicator yang bisa digunakan dalam rangka meminimalisirkan angka kemiskinan, tetapi jika semakin tinggi ketergantungan masyarakat tidak produktif terhadap masyarakat atau penduduk yang produktif ini memandakan angaka kemiskinan semakin tinggi. Sedangkan Indeks Pembangunan Manusia (IPM) juga sebagai indikator pengukuran tinggi rendahnya angka kemiskinan suatu daerah, namun indikator ini sifatnya belum mampu mewakili semua indikator pendukung lainnya yang dapat mengurangi angka kemiskinan. Angkatan Kerja adalah orang yang sudah bekerja dan yang belum bekerja (pengangguran) indikator ini juga digunakan sebagai indikator pengukuran terhadap tinggi rendahnya kemiskinan di suatu daerah, tetapi jika angkatan kerja yang sudah bekerja lebih dominan dibandingkan dengan angkatan kerja yang belum bekerja tentunya ini sudah mewarnai terhadap pengurangan angka kemiskinan dengan cara menciptakan lapangan kerja atau memanfaatkan potensi sumberdaya secara optimal.

\section{Daftar Pustaka}

Arsyad, Lincolin, 2015, Ekonomi Pembangunan (Edisi 5) Penerbit: UPP STIM YKPN

Budiono, S . (2000). Bunga Rampai Hiperkes dan Keselamatan Kerja. Semarang : Badan Penerbit Universitas Diponegoro.

BPS, 2016, https://www.bps.go.id/menu/24/unduh.html (kemiskinan adalah ketidak mampuan dalam mencapai standar hidup)

BPS, 2002 https://www.bps.go.id/subject/23/kemiskinan-dan-ketimpangan.html

Ghozali, 2009, Analisis Aplikasi Multivariate, UNDIP, Semarang Tahun 2009

Hamzah dkk, 2019. Pengaruh Investasi Dan Inflasi Terhadap Jumlah Penduduk Miskin di Kabupaten Jember Tahun 2000-2015. e-Journal Ekonomi Bisnis dan Akuntansi, 6(1), 81-84.

Hamzah, dkk (2019) Pengaruh Investasi Dan Inflasi Terhadap Jumlah Penduduk Miskin .. e-Journal Ekonomi Bisnis dan Akuntansi, 2019, Volume VI (1) : 81-84

Mirza, Denni Sulistio (2011) Pengaruh Kemiskinan, Pertumbuhan Ekonomi, dan Belanja Modal JEJAK, Volume 4, Nomor 2, September 2011

Sudirman, M., 2017, The Factors that Affect Poverty in Jambi Province in Perspective Islam. Saudi Journal of Business and Management Studies ISSN 2415-6663 (Print) Scholars Middle East Publishers ISSN 2415-6671 (Online) Dubai, United Arab Emirates Website: http://scholarsmepub.com/

Saharuddin dkk, 2016, Pengaruh Jumlah Penduduk, Pendidikan Dan Pertumbuhan Ekonomi Terhadap Kemiskinan Di Kabupaten Lebak. Jurnal Ilmu Ekonomi, 6(1), April 2016, 100-114

Sudirman, S., dan Ahmadi, A., 2014. Pengaruh Pendidikan, Upah dan Angka Harapan Hidup terhadap Produktivitas Tenaga Kerja Sektor Ekonomi di Provinsi. Jurnal Ilmiah Universitas Batanghari Jambi, 14(4), 65-72.

Sugi dkk, 2019, Pemodelan Jumlah Penduduk Miskin Di Jawa Tengah Menggunakan Geographically Weighted Regression (GWR). Jurnal Litbang Sukowati In Press, 4(2), Mei 2021, 48-57, p-ISSN: 2580-541X, e-ISSN: 2614-3356

Sumarsono, (2007) Sosiolinguistik : Penerbit : Pustaka Pelajar, Jakarta

Sukirno, sadono (2004), Makroekonomi Teori Pengantar Edisi 6 Yogyakarta BPFE Edisi Ketiga Jakarta Raja Grafindo Persada

Sari, dkk (2020). Analisis Pengaruh Indeks Pembangunan Manusia Dan Kemiskinan Terhadap Pertumbuhan Ekonomi Kabupaten/Kota Di Provinsi Kepulauan Bangka Belitung Tahun 2010-2017 Equity: Jurnal Ekonomi Vol. 8 (1): Juni 2020 Diterima: 28-5-2020; Disetujui: 4-6-2020 p-ISSN: 1978-3795; e-ISSN: 2721-6721

Todaro, 2003, Pembangunan Ekonomi, Edisi 9, Jilid 1

Usman dkk, 2018, Pengaruh Jumlah Penduduk, Pengangguran dan Pertumbuhan Ekonomi Terhadap Kemiskinan di Provinsi Kepulauan Riau. Jurnal Ekonomi Regional Unimal, 1(2), Agustus 2018 E-ISSN : 2615-126X URL:

UNDP, (2009) https://www.id.undp.org/content/indonesia/id/home.html (Mengentaskan Kemiskinan) 